\title{
One variant of the collocation-iterative method of solving integro-functional equations
}

\author{
I. Konet, K. Heseleva \\ Kamianets-Podilskyi National Ivan Ohiienko Univesity, Kamianets-Podilskyi, Ukraine \\ Corresponding author. E-mail: geseleva1702@gmail.com
}

Paper received 25.01.21; Accepted for publication 12.02.21.

\section{https://doi.org/10.31174/SEND-NT2021-250IX31-03}

\begin{abstract}
The construction of exact solutions of integro-functional equations is possible only in some cases, so the questions of studying approximate methods for solving these equations, convergence conditions and estimating the errors are relevant. The article considers the construction of approximate solutions of linear integro-functional equations. It is shown that, under certain conditions, such solutions can be obtained by applying one variant of the collocation-iterative method to the problem. The algorithm of the method and sufficient convergence conditions are indicated.
\end{abstract}

Keywords: linear integro-functional equation, Fredholm integral equation of the second kind, collocation-iterative method, approximate solution, collocation nodes.

Introduction. Many problems of applied and theoretical nature cannot be imagined without the construction and reaserch of various mathematical models. Economics, biology, technology and many other fields of human activity are increasingly based in their research on the results obtained in the theory of operator equations. Therefore, many boundary value problems for differential equations with argument deviation are models of different natural processes. The theoretical foundations of these problems are laid in the works of A. Samoilenko, M. Perestyuk [11], A.Luchka [7] and other scientists.

Such problems are reduced to solving integrofunctional equations. The exact solution of these equations can be found only in some simple cases. In more complex cases, the exact solution cannot be expressed by elementary functions. Therefore, approximate methods are important. The research of the projection-iterative method and its generalizations are devoted to the works of A. Luchka [8], N. Kurpel [4] and other. The methods of projection-iterative type include the collocation-iterative method, which arose as a result of the synthesis of the method of successive approximations and the method of collocation. It is quite effective in terms of finding approximate solutions of different types of integrofunctional equations $[1,2]$. The application of the collocation-iterative method for solving integro-functional equations is the main object of study of this article.

Analysis of recent research and publications. The research and theoretical substantiation of the collocationiterative method with respect to one-dimensional and multidimensional Fredholm integral equations, the study of the rate of convergence of the method depending on the smoothness of the initial data are devoted to the work of A.Y. Luchka [7, 9] and E.M. Lutsev [6].

The application of the collocation-iterative method to find the solution of the boundary value problem for ordinary differential equations with parameters is devoted to the works of Poselyuzhna V.B. and Semchyshyna L.M. [10], Kucheruk T. [5]. In these works, the question of applying the collocation-iterative method (both stationary and nonstationary) to find the solution of the boundary value problem for ordinary differential equations with parameters, for differential equations with small nonlinearity, and for the boundary value problem for ordinary differential equations with momentum influence and parameters. The application of a modified collocationiterative method for solving integral Fredholm equations of the 2nd kind and differential equations with small nonlinearity is also substantiated.

Despite the considerable many of work devoted to various aspects of the theory of approximate methods for solving different types of operator equations, the task of obtaining compatibility conditions and constructing new methods for finding approximate solutions of such equations is still far from being fully solved.

The purpose and objectives of the research. Construction and research of the studied publishing developments of integra-functional levels by collocationinteractive method. Describe the conditions and rate of convergence of this method and approximation errors.

\section{Materials and methods}

In space $L_{2}(a ; b)$ - real and measuring on the interval $(a ; b)$ of functions, summable with a square, consider the integro-functional equation form

$$
y(x)-p(x) y(h(x))=f(x)+\int_{a}^{b} K(x ; t) y(t) d t, x \in(a ; b),
$$

$y(x)=0, x \notin(a ; b)$,

where $f(x)$ - known, and $y(x)$ - unknown functions from $L_{2}(a ; b)$. Regarding the functions $h(x), p(x), K(x ; t)$ we assume that they, according to on the interval $[a ; b]$ and on the squared $[a ; b]^{2}$ satisfy the conditions:

$|p(x)| \leq \bar{p}<\infty$,

$h(x)$-differentiable on $[a ; b]$ and

$h^{\prime}(x) \geq l>0, x-h(x) \geq \sigma>0$,

bb

$\int_{a}^{b} \int_{a}^{2} K^{2}(x ; t) d x d t=B^{2}<\infty$.

We show that equation (1) under conditions (2) - (4) can be reduced to the integral Fredholm equation of the second kind. Next to the integral completely continuous operator $K$ which has a form 


$$
\begin{aligned}
& (K v)(x)=\int_{a}^{b} K(x ; t) v(t) d t, \forall v(x) \in L_{2}(a ; b) \\
& \text { we consider the operator } S \quad \text { such as } \\
& (S v)(x)=\left\{\begin{array}{l}
v(x), x \in\left[a ; h^{-1}(a)\right] \\
v(x)-p(x) v(h(x)), x \in\left[h^{-1}(a) ; b\right]
\end{array}\right.
\end{aligned}
$$

where $v(x)$ - arbitrary function from $L_{2}(a ; b)$.

Note that this operator, like the operator $K$, acts from $L_{2}(a ; b)$ to $L_{2}(a ; b)$. It is easy to show that the operator $S$ linear. Conditions (2), (3) guarantee its limitation. Really,

$$
\|S\|=\sup \frac{(S v)(x)}{v(x)} \leq 1+\left|\frac{p^{2}(x)}{h^{\prime}(x)}\right|^{\frac{1}{2}} \leq 1+\frac{\bar{p}}{\sqrt{l}}<\infty,
$$

where sup taken on $v(x) \in L_{2}(a ; b), v(x) \neq 0$.

These conditions suggest that the operator $S$ reversible. Inverse operator looks

$$
\begin{gathered}
\left(S^{-1} v\right)(x)=\left\{\begin{array}{c}
v(x), x \in\left[a ; h^{-1}(a)\right], \\
v(x)+\sum_{i=1}^{s} v\left(h^{i}(x)\right) \prod_{k=0}^{i-1} p\left(h^{k}(x)\right),
\end{array}\right. \\
x \in \Delta_{S}, s=\overline{1, m} .
\end{gathered}
$$

Here, as in the future,

$$
\begin{gathered}
\Delta_{s}=\left[c_{s-1} ; c_{s}\right], \\
c_{0}=a, c_{s}=h^{-1}\left(c_{s-1}\right), c_{m}=b, \\
h^{k}(x)=h\left(h^{k-1}(x)\right), s=\overline{1, m .}
\end{gathered}
$$

So, in other words, expression (6) - is a solution of a functional equation

$$
\begin{aligned}
& y(x)-p(x) y(h(x))=u(x), x \in[a ; b], \\
& y(x)=0, x \notin[a ; b],
\end{aligned}
$$

(where $u(x)$ - known, $y(x)$ - unknown functions) using the method of steps. Condition (3) guarantees the fact that the number of steps $m$ are finite and $m \leq\left(\frac{b-a}{\sigma}\right)$.

It is easy to make sure that the operator $S^{-1}$, as well as the operator $S$, linear and limited. Thus, given the above considerations, we can consider equation (1) as an operator equation

$$
(S y)(x)=f(x)+(K y)(x),
$$

where $f(x)$ - known, $y(x)$ - unknown functions from $L_{2}(a ; b)$.

Let $(S y)(x)=u(x)$, then $y(x)=\left(S^{-1} u\right)(x)$ and we are of the equation (7) go to the equation $u(x)=f(x)+(T u)(x)$.
Operator $T=K S^{-1}$ is Fredholm as a superposition of Fredholm and linear limited operators. In other words, using the above-mentioned substitution, we transform the integro-functional equation (1) into the integral Fredholm equation of the second kind

$u(x)=f(x)+\int_{a}^{b} T(x ; t) u(t) d t$,

with a completely continuous integral operator $T$ and $T(x ; t)=\left\{\begin{array}{c}K(x ; t)+\sum_{i=1}^{m-s} K\left(x ;\left(h^{-1}\right)^{k}(t)\right), t \in \Delta_{s}, \\ K(x ; t), t \in\left(c_{m-1} ; b\right), s=\overline{1, m-1}, x \in(a ; b),\end{array}\right.$

where $\left(h^{-1}\right)^{k}(t)=h^{-1}\left(\left(h^{-1}\right)^{k-1}(t)\right)$.

We can apply the method of successive approximations, collocation and some collocation-iterative methods to the problem (1) [3, 6]. Moreover, the most effective of convergence conditions is the last method, accordingly, the previous two methods can be considered as partial cases [5].

Let $\left\{\varphi_{i}(x)\right\}$ - linearly-independent system of functions from $L_{2}(a ; b)$. Suppose, that based on the initial approximation $y_{0} \in L_{2}(a ; b)$ and functions $s_{0}(x)$ such as

$$
\begin{gathered}
y_{0}(x)-p(x) y_{0}(h(x))=s_{0}(x), x \in[a ; b], \\
y_{0}(x)=0, x \notin[a ; b],
\end{gathered}
$$

we found an approximation $y_{k-1}(x)$ and function $s_{k-1}(x)$. The next approximation $y_{k}(x)$ we find from the functional equation

$$
\begin{gathered}
y_{k}(x)-p(x) y_{k}(h(x))=f(x)+\int_{a}^{b} K(x ; t) z_{k}(t) d t, x \in[a ; b], \\
y_{k}(x)=0, x \notin[a ; b],
\end{gathered}
$$

which

$$
z_{k}(x)=y_{k-1}(x)+w_{k}(x), \quad w_{k}(x)=\sum_{j=1}^{n} a_{j}^{k} \eta_{j}(x) .
$$

Unknown coefficients $a_{j}^{k}=a_{j}^{k}(n)$ determined from the condition

$$
r_{k}\left(x_{i}\right)=0, i=\overline{1, n},
$$

where

$$
\begin{gathered}
r_{k}\left(x_{i}\right)=f(x)+\int_{a}^{b} K(x ; t) z_{k}(t) d t-z_{k}(x)+p(x) z_{k}(h(x)), \\
x_{i} \in[a ; b] \text { - collocation nodes, } i=\overline{1, n} .
\end{gathered}
$$

System of functions $\left\{\eta_{j}(x)\right\}, j=\overline{1, n}$ are determined from functional equations

$$
\begin{gathered}
\eta_{j}(x)-p(x) \eta_{j}(h(x))=\varphi_{j}(x), x \in[a ; b], \\
\eta_{j}(x)=0, x \notin[a ; b] .
\end{gathered}
$$

Results and discussion. The algorithm is given by replacement $u_{k}(x)=\left(S y_{k}\right)(x), \alpha_{k}(x)=\left(S w_{k}\right)(x)$ reduces to a collocation-iterative method of solving integral equa- 
tion (9) with a kernel having the form (10). Therefore, the following statement will take place.

Theorem. If one is not a point of the spectrum of the integral operator $T$ equation (9), and system of functions $\left\{\varphi_{i}(x)\right\}$ is complete in space $L_{2}(a ; b)$, then there will be such a number $n$, that method (11) - (15) will be convergent, and convergence rate will increase with increasing $n$.

Here are some sufficient conditions for the convergence of the method (11) - (15).

Suppose, as mentioned above, functions $p(x), h(x)$ and $K(x ; t)$ satisfy the conditions (2) - (4). System of functions $\left\{\varphi_{i}(x)\right\}$ is complete and orthogonal in $L_{2}(a ; b)$. The answer to the question of which $n$ the above collocation-iterative method will be convergent, can be obtained using the algorithm. The essence of these algorithm is follows.

First, we construct functions by a recurrent formula

$U_{s}^{\prime}(x ; t)=U_{s-1}(x ; t)-\alpha_{s} E_{s}(x) \omega_{s}(t), s=1,2, \ldots$,

where

$$
\begin{aligned}
& E_{s}(x)=\int_{a}^{b} U_{s-1}(x ; t) \eta_{s}(t) d t, \alpha_{s}^{-1}=\int_{a}^{b} \varphi_{s}^{2}(t) d t, \\
& \omega_{s}(t)=\lambda_{s}(t)-\int_{a}^{b} U_{s-1}(x ; t) \varphi_{s}(x) d x, \\
& \lambda_{s}(t)=\varphi_{s}(t)-p\left(h^{-1}(t)\right) \varphi_{s}\left(h^{-1}(t)\right), t \in[a ; b], \\
& \varphi_{s}(t)=0, \text { when } t \notin[a ; b] .
\end{aligned}
$$

We take $U_{0}(x, t)=K(x ; t)$, and we find functions

$\eta_{s}(x)$ by solving the functional equation (15).

After that we write function

$U_{s}(x ; t)=U_{s}^{\prime}(x ; t)-\varphi_{s}(x) \beta_{s}(t), s=1,2, \ldots$,

where

$\beta_{s}(t)=\alpha_{s} \int_{a}^{b} U_{s}^{\prime}(x ; t) \varphi_{s}(x) d x$.

Next, we solve the functional equation

$$
\begin{gathered}
L_{s}(x ; t)-p\left(h^{-1}(t)\right) L_{s}\left(x ; h^{-1}(t)\right)=U_{s}(x ; t), t \in[a ; b], \\
L_{s}(x ; t)=0, t \notin[a ; b],
\end{gathered}
$$

and we find the function $L_{s}(x ; t), s=1,2, \ldots$.

Then calculate

$q_{s}^{2}=\int_{a}^{b} \int_{a}^{b} L_{s}^{2}(x ; t) d x d t$.

It turns out that if $q_{s}<1$, then we come to the conclusion that method (11) - (15) will be convergent. If $q_{s} \geq 1$ , then the question of the convergence of the method remains open. Gradually increasing the number of coordinate functions $\varphi_{i}(x), i=s+1, s+2, \ldots$, according to the same recurrent formulas (16) - (23) we continued the calculation until we come to such $n$, that inequality $q_{s}<1$ will be.
The convergence rate of collocation-iterative method will be characterized by inequality

$\left\|y^{*}(x)-y_{k}(x)\right\| \leq C_{n} \cdot q_{n}^{k-1} \cdot\left\|y^{*}(x)-y_{0}(x)\right\|$,

$C_{n}$ - some positive constant, and $y^{*}(x)$ - exact solution of the integro-functional equation

$$
y(x)-p(x) y(h(x))=f(x)+\int_{a}^{b} K(x ; t) y(t) d t, x \in(a ; b),
$$

$y(x)=0, x \notin(a ; b)$,

where $f(x)$ - known, a $y(x)$ - unknown functions from $L_{2}(a ; b)$.

This estimate can be used to finding the number of iterations, which necessary to reduce the initial error by the required number of times.

There also will be a constructive estimate:

$\left\|y^{*}(x)-y_{k}(x)\right\| \leq \frac{p_{n} q_{n}^{k-s}}{1-q_{n}} \cdot\left\|y_{s}(x)-z_{s}(x)\right\|$,

where $p_{n}$ - some positive number, $1 \leq s \leq k$, and $z_{s}(x)$ looks like (12).

Direct calculations according to method (11) - (15) should be performed as follows. First, we define a linearly-independent system of functions $\left\{\varphi_{j}(x)\right\}, \quad j=\overline{1, n}$ and by the formula (15) find the system $\left\{\eta_{j}(x)\right\}$. After that we find functions

$K_{j}(x)=\int_{a}^{b} K(x ; t) \eta_{j}(t) d t, j=\overline{1, n}$.

Next by the formula

$\beta_{i j}=\varphi_{j}\left(x_{i}\right)-K_{j}\left(x_{i}\right)$,

we can find the elements of the matrix $\Lambda$ (тут $x_{i}, i=\overline{1, n}$ - collocation nodes). Then we find the inverse matrix $\Lambda^{-1}$ and move on to main calculations.

So, let the approximation $y_{k-1}(x)$ and according to function $s_{k-1}(x)$ already set. Then we perform the iteration

$v_{k}(x)=f(x)-\int_{a}^{b} K(x ; t) y_{k-1}(t) d t$,

and we find a discrepancy

$\varepsilon_{k}(x)=v_{k}(x)-s_{k-1}(x)$. (30)

According to the formula

$b_{i}^{k}=\varepsilon_{k}(x),(31)$

we find the coordinates of the vector $b_{i}^{k}$.

We write the equation $\Lambda \bar{a}_{k}=\bar{b}_{k}$ and we find its solution $\bar{a}_{k}=\Lambda^{-1} \bar{b}_{k}=\left(a_{1}^{k}, a_{2}^{k}, \ldots, a_{n}^{k}\right)$.

We construct functions

$$
s_{k}(x)=v_{k}(x)+\sum_{j=1}^{n} a_{j}^{k} K_{j}(x), j=\overline{1, n} \text {. }
$$

Then the approximate solution found from the functional equation 


$$
\begin{gathered}
y_{k}(x)-p(x) y_{k}(h(x))=s_{k}(x), x \in(a ; b), \\
y_{k}(x)=0, x \notin(a ; b) .
\end{gathered}
$$

Conclusions. The results obtained in the article expand the scope of the collocation-iterative method and enrich the theory of integro-functional equations. The developed algorithm of the method can be used to find solutions to specific mathematical problems that come from physics, biology, economics and other scientific fields. It is shown that the collocation-iterative method of solving integrofunctional equations makes it possible to find solutions to the problem. When using this method, at each step of the iteration there is a need to solve a linear system of algebraic equations. Since the basic matrix of the system is nondegenerate and the same for each iteration step, it is advisable to find the inverse matrix at the beginning of this process and then use it step by step to find approximate solutions. It should be kept in mind that the obtained results of the convergence method and constructive estimates of the errors of the method are important.

\section{ЛИТЕРАТУРА}

1. Геселева К. Г. Колокаційний та колокаційно ітеративний методи розв'язання інтегро-функціональних рівнянь 3 малою нелінійністю. Математичне та комп 'ютерне моделювання. Серія: Фізико-математичні науки: зб. наук. пр. / Ін-т кібернетики ім. В. М. Глушкова НАНУ, Кам'янець-Поділ. нац. ун-т ім. Івана Огієнка. Кам'янецьПодільський, 2015. Вип. 12. С. 19-27.

2. Геселева К. Г. Колокаційно-ітеративний метод розв'язування лінійних інтегро-функціональних рівнянь. Математичне та комп'ютерне моделювання. Серія: Фізико-математичні науки: зб. наук. пр. / Ін-т кібернетики ім. В. М. Глушкова НАНУ, Кам'янець-Поділ. нац. ун-т ім. Івана Огієнка. Кам'янець-Подільський, 2017. Вип. 16. С. 41-48.

3. Конет И. М., Геселева К. Г. Коллокационный и коллокационно-итеративный методы ришения интегрофункционального уравнения. Часопіс «Веснік Брэсикага універсітэта». Серыя 4. Фізіка. Матэматыка. 2017. № 2. C. 82-89.

4. Курпель Н.С. Проекционно-итеративные методы решения линейных дифференциальных и интегральных уравнений. Наукова думка, Київ, 1968. 244 с.

5. Кучерук Т. А. Крайова задача для звичайних диференціальних рівнянь 3 додатковими умовами та іiі

розв'язання ітераційним методом. Доп. НАН Украӥни. 2002. № 12. С. 17-20.

6. Луцев Е. М. Коллокационно-итеративный метод решения линейных интегральных уравнений Фредгольма второго рода. Методы исследования дифференциальных и интегральных операторов. Киев : Наук. думка, 1989. С. 132138.

7. Лучка А.Ю. Интегральные уравнения и методы их решения. Кибернетика и систем. анализ. - 1996. №3. - С.8296.

8. Лучка А.Ю. Критерий сходимости проекционноитеративного метода для нелинейных уравнений. (Препринт. АН УССР. Ин-т математики; 82.24), Київ, 1980. $54 \mathrm{c.}$

9. Лучка А.Ю. Проекционно-итеративные методы решения линейных дифференциальных и интегральных уравнений. Киев: Наук. думка, 1980. 288 с.

10. Поселюжна В. Б., Семчишин Л. М. Колокаційноітеративний метод розв'язування диференціальних та інтегральних рівнянь : монографія / Терноп. нац. екон. ун-т. Тернопіль : Економічна думка, 2013. 203 с.

11. Самойленко А.М., Перестюк Н.А. Дифференциальные уравнения с импульсным воздействием. Вища школа. Київ, 1987. 145 с.

\section{REFERENCES}

1. Heseleva K.H. Collocation and collocation iterative methods for solving integro-functional equations with small nonlinearity. Mathematical and computer modelling. Series: Physical and mathematical sciences: scientific journal / V.M. Glushkov Institute of Cybernetics of National Academy of Sciences of Ukraine, Kamianets-Podilskyi National Ivan Ohiienko University. - Kamianets-Podilskyi: KamianetsPodilskyi National Ivan Ohiienko University, 2015. ISSUE 12. P. 19-27.

2. Konet I.M., Heseleva K.H. Collocation and collocationiterative methods for solving the integro-functional equation. Vesnik of Brest University. Series 4. Physics. Mathematics. Scientific-Theoretical Journal of Brest state university named after A.S. Pushkin. - Brest, 2017. № 2. P. 82-89.

3. Heseleva K.H. Collocation-iterative method for solving linear integro-functional equations. Mathematical and computer modelling. Series: Physical and mathematical sciences: scientific journal / V.M. Glushkov Institute of Cybernetics of National Academy of Sciences of Ukraine, KamianetsPodilskyi National Ivan Ohiienko University. - KamianetsPodilskyi: Kamianets-Podilskyi National Ivan Ohiienko University, 2017. ISSUE 16. P. 41-48.

4. Kurpel N.S. Projection-iterative methods for solving linear differential and integral equations. Naukova Dumka, Kyiv, 1968. $244 \mathrm{p}$.
5. Kucheruk T.A. Boundary problem for ordinary differential equations with additional conditions and its solution by the iterative method. Reserch NAS of Ukraine. 2002. № 12. P. $17-20$.

6. Lutsev E.M. Collocation-iterative method for solving linear integral Fredholm equations of the second kind. Methods of research of differential and integral operators. Kiev: Naukova Dumka, 1989. P. 132-138.

7. Luchka A.Y. Integral equations and methods of their solution. Cybernetics and systems analysis. - 1996. №3. - P.82-96.

8. Luchka A.Y. Convergence criterion of the projection-iterative method for nonlinear equations. (Preprint. Academy of Sciences of the USSR. Inst. Of Mathematics; 82.24), Kyiv, 1980. $54 \mathrm{p}$.

9. Luchka A.Y. Projection-iterative methods for solving linear differential and integral equations. Kiev: Naukova Dumka, 1980. $288 \mathrm{p}$.

10. Poselyuzhna V.B., Semchyshyn L.M. Colocation-iterative method for solving differential and integral equations: monograph / Ternopil. nat. econ. un-t. Ternopil: Economichna

11. Samoilenko AM, Perestyuk N.A. Differential equations with impulse action. Vyshcha shkola. Kyiv, 1987. 145 p. Dumka, 2013. 203 p. 